\title{
The Role of $\mathrm{GLU}_{\mathrm{K} 5}$-Containing Kainate Receptors in Entorhinal Cortex Gamma Frequency Oscillations
}

\author{
Heather L. Stanger, ${ }^{1}$ Rebekah Alford, ${ }^{2}$ David E. Jane, ${ }^{3}$ and Mark O. Cunningham ${ }^{1}$ \\ ${ }^{1}$ Institute of Neuroscience, Faculty of Medical Sciences, Newcastle University, The Medical School Framlington Place, \\ Newcastle upon Tyne NE2 4HH, UK \\ ${ }^{2}$ The Molecular Biology, Biochemistry and Bioinformatics (MB3) Program, Towson University, Room 360, Smith Hall, \\ 8000 York Road, Towson, MD 21251-0001, USA \\ ${ }^{3}$ Department of Physiology and Pharmacology, MRC Centre for Synaptic Plasticity, School of Medical Sciences, \\ University of Bristol, University Walk, Bristol BS8 1TD, UK
}

Correspondence should be addressed to Mark O. Cunningham, mark.cunningham@ncl.ac.uk

Received 5 June 2008; Revised 21 July 2008; Accepted 22 September 2008

Recommended by C. Andrew Chapman

\begin{abstract}
Using in vitro brain slices of hippocampus and cortex, neuronal oscillations in the frequency range of 30-80 Hz (gamma frequency oscillations) can be induced by a number of pharmacological manipulations. The most routinely used is the bath application of the broad-spectrum glutamate receptor agonist, kainic acid. In the hippocampus, work using transgenic kainate receptor knockout mice have revealed information about the specific subunit composition of the kainate receptor implicated in the generation and maintenance of the gamma frequency oscillation. However, there is a paucity of such detail regarding gamma frequency oscillation in the cortex. Using specific pharmacological agonists and antagonists for the kainate receptor, we have set out to examine the contribution of kainate receptor subtypes to gamma frequency oscillation in the entorhinal cortex. The findings presented demonstrate that in contrast to the hippocampus, kainate receptors containing the GLU $\mathrm{K}_{5}$ subunit are critically important for the generation and maintenance of gamma frequency oscillation in the entorhinal cortex. Future work will concentrate on determining the exact nature of the cellular expression of kainate receptors in the entorhinal cortex.
\end{abstract}

Copyright (c) 2008 Heather L. Stanger et al. This is an open access article distributed under the Creative Commons Attribution License, which permits unrestricted use, distribution, and reproduction in any medium, provided the original work is properly cited.

\section{INTRODUCTION}

KARs are made up of various combinations of five subunits: $\mathrm{GLU}_{\mathrm{K} 5}, \mathrm{GLU}_{\mathrm{K} 6}, \mathrm{GLU}_{\mathrm{K} 7}, \mathrm{KA} 1$, and KA2 [1, 2] which are abundantly expressed in the neocortex [3]. These subunits make up tetramers of either homomeric or heteromeric assemblies, with $\mathrm{GLU}_{\mathrm{K} 5-7}$ being able to form functional homomeric receptors $[1,4]$. KA1 and KA2 cannot form functional receptors when expressed alone $[5,6]$, yet are able to form functional KARs when expressed heteromerically with other subunits $[1,7,8]$. Differential patterns of expression of KARs in the CNS coupled with the existence of splice variants and mRNA editing suggest complex neurophysiological roles for the various subunits, and different roles in neuronal networks depending on their localization $[9,10]$.

Of particular interest is the role of KARs in the generation and maintenance of network neuronal oscillatory activity in cortical regions $[9,10]$. Gamma frequency oscillations occur between $30-80 \mathrm{~Hz}$ and have been observed in many areas of the brain, including the hippocampus [11-13] and cortical regions [14-16]. Cortical gamma oscillations are important in higher brain functions, such as learning, memory, and cognition [17-19], as well as processing of sensorimotor information $[15,16,20]$. In carrying out these functions, cortical gamma oscillations are implicated in various central processes, including long-term potentiation (LTP) and synaptic plasticity [21], with important roles in temporal regulation of neuronal activity.

Gamma frequency oscillations are recordable from the MEC during wakefulness in humans $[22,23]$, as well as in vivo in rodents [12], in vitro from perfused guinea pig brains [24, 25], and isolated rat brain slices [26, 27]. These gamma oscillations in the MEC play a role in the formation, processing, storage, and retrieval of memories $[17,18]$. Previously it has been demonstrated in an in vitro preparation of the MEC that application of nanomolar 
concentrations of kainate $(200-400 \mathrm{nM})$ can induce persistent gamma frequency oscillations [26-28]. Using this in vitro model of MEC gamma frequency oscillations it has been elucidated that this activity is primarily generated by inhibitory-based neuronal networks [29-31]. A similar mechanism for the generation of gamma frequency activity has been demonstrated in both the hippocampus and neocortex [32, 33].

To date our understanding of the role of the KARs in neuronal network activity has been hampered by a paucity of selective pharmacological agents. The competitive AMPA/KAR antagonist, 2,3-dihydroxy-6-nitro-7sulfamoyl-benzo[f]quinoxaline (NBQX), shows little selectivity between AMPA receptors and KARs at high concentrations, yet at low concentrations $(1 \mu \mathrm{M})$ can be used to block AMPA receptors, and isolate KAR responses [34, 35]. However, NBQX shows no selectivity between different KAR subunits. The role of $\mathrm{GLU}_{\mathrm{K} 5}$ and $\mathrm{GLU}_{\mathrm{K} 6}$ subunits in neuronal oscillatory activity in the hippocampus has been previously investigated using receptor knockout mice $[9,10]$. However, interpretation of work using transgenic models should be viewed in the light of the knowledge that compensatory factors may play a role. The recent development of pharmacological agents with specificity for distinct subunits has led to the possibility of a detailed pharmacological investigation of the role of specific KARs in cortical gamma frequency oscillations. (S)-3-(2-Carboxybenzyl)willardiine (UBP302) is a novel selective $\mathrm{GLU}_{\mathrm{K} 5}$-containing $\mathrm{KAR}$ antagonist, with activity at both homomeric and heteromeric $\mathrm{GLU}_{\mathrm{K} 5}$ containing receptors $[36,37]$. The activity of UBP302 on $\mathrm{GLU}_{\mathrm{K} 7}$ is controversial, Dolman et al. [37] showed that UBP296 (racemic form of UBP302) only weakly inhibited $\left[{ }^{3} \mathrm{H}\right]$ kainate binding to human $\mathrm{GLU}_{\mathrm{K} 7}\left(\mathrm{~K}_{i}\right.$ value of $374 \pm 122 \mu \mathrm{M})$. However, in an electrophysiological assay UBP302 was found to block rat homomeric $\mathrm{GLU}_{\mathrm{K} 7}$ receptors with an $\mathrm{IC}_{50}$ value of $4 \mu \mathrm{M}$ but at a concentration of $100 \mu \mathrm{M}$ only very weakly blocked rat $\mathrm{GLU}_{\mathrm{K} 6} / \mathrm{GLU}_{\mathrm{K} 7}$ receptors [38]. 5-Carboxy-2,4-di-benzamido-benzoic acid (NS3763) is another novel glutamate antagonist, which is selective and noncompetitive for homomeric $\mathrm{GLU}_{\mathrm{K} 5}$ containing KARs [39, 40]. (RS)-2-amino-3-(3-hydroxy-5tert-butyl-isoxazol-4-yl)propanoic acid (ATPA) is a selective $\mathrm{GLU}_{\mathrm{K} 5}$-containing receptor agonist [41]. ATPA has been shown to depress excitatory and GABAergic synaptic transmission in the hippocampus $[42,43]$. However, Cossart et al. [35] demonstrated that lower concentrations of ATPA could directly depolarise hippocampal GABAergic interneurons leading to increases in the levels of tonic inhibition onto pyramidal neurons. More recently, similar concentrations of ATPA to that used in the Cossart et al. [35] study have been shown to facilitate both evoked and action potential-independent glutamate release in the neocortex [44].

The data presented here demonstrates a role of $\mathrm{GLU}_{\mathrm{K} 5}$ containing KARs in the MEC by examining the contribution of these receptor subtypes to gamma frequency oscillations. Using a pharmacological approach, we have demonstrated that $\mathrm{GLU}_{\mathrm{K} 5}$-containing KARs are important for the maintenance of gamma frequency oscillations in the MEC. Moreover, the selective activation of $\mathrm{GLU}_{\mathrm{K} 5}$ containing KARs can induce persistent gamma frequency oscillations in the MEC. We also demonstrate that it is the specific activation of homomeric $\mathrm{GLU}_{\mathrm{K} 5}$-containing KARs that is important for the generation of gamma frequency oscillations in the MEC.

\section{MATERIAL AND METHODS}

\subsection{Preparation of EC-hippocampal slices}

All procedures involving animals were carried out in accordance with UK Home Office Legislation. Male Wistar rats, weighing $>150$ grammes, were first anaesthetised by inhalation of the volatile anaesthetic isofluorane. This was immediately followed by intramuscular injection of a terminal dose of $\geq 100 \mathrm{mg} / \mathrm{kg}$ ketamine and $\geq 10 \mathrm{mg} / \mathrm{kg}$ xylazine. After confirmation of deep anaesthesia, rats were intracardiacally perfused with $\sim 50 \mathrm{~mL}$ sucrose-modified artificial cerebral spinal fluid (aCSF), composed of (in millimolar (mM)): 252 sucrose, $3 \mathrm{KCl}, 1.25 \mathrm{NaH}_{2} \mathrm{PO}_{4}, 2 \mathrm{MgSO}_{4}, 2 \mathrm{CaCl}_{2} \cdot 2 \mathrm{H}_{2} \mathrm{O}, 10$ glucose, and $24 \mathrm{NaHCO}_{3}$. All salts were obtained from $\mathrm{BDH}$ Laboratory Supplies (Poole, UK), except $\mathrm{MgSO}_{4}$ which was obtained from Sigma Chemical Co (Mo, USA).

The whole brain was rapidly removed and maintained in a bath of cold sucrose-modified aCSF $\left(4-5^{\circ} \mathrm{C}\right)$ during the dissection procedure. Horizontal slices $(450 \mu \mathrm{m}$ thick) were cut using a vibroslice (Leica VT1000S). Transverse EC-hippocampal slices were then transferred either to a holding chamber or directly to the recording chamber. They were maintained at $32 \pm 1{ }^{\circ} \mathrm{C}$, at the interface between a continuous perfusion $(\sim 2-3 \mathrm{~mL} / \mathrm{min})$ of $\mathrm{NaCl}$-based aCSF (containing (in $\mathrm{mM}$ ): $126 \mathrm{NaCl}, 3 \mathrm{KCl}, 1.25 \mathrm{NaH}_{2} \mathrm{PO}_{4}$, $1 \mathrm{MgSO}_{4}, 1.2 \mathrm{CaCl}_{2} \cdot 2 \mathrm{H}_{2} \mathrm{O}, 10$ glucose, $\left.24 \mathrm{NaHCO}_{3}\right)$ and humidified carbogen gas $\left(95 \% \mathrm{O}_{2} / 5 \% \mathrm{CO}_{2}\right)$. Slices were allowed to equilibrate for 60 minutes before any recordings were taken.

\subsection{Electrophysiological recording and drug application}

Extracellular recordings were taken using glass electrodes pulled from borosilicate glass capillaries (GC129 TF-10, $1.2 \mathrm{~mm}$ OD/0.94 mm ID) (Harvard Apparatus, Kent, UK) using a Flaming/Brown micropipette puller, model P-97 (Sutter Instrument Co., Calif, USA). This created electrodes with resistances of 2-4 M $\Omega$. Electrodes were filled with $\mathrm{NaCl}-$ based aCSF and positioned in Layer III of the MEC. Control readings were taken from slices before drug application to confirm that any network activity seen following treatment was due to the presence of drugs.

To evoke gamma frequency oscillations, $400 \mathrm{nM}$ kainic acid ((2S,3S,4S)-3-carboxymethyl-4-(prop-1-en-2-yl) pyrrolidine-2-carboxylic acid; Tocris Cookson, Bristol, UK) was bath applied to EC-hippocampal slices and left to equilibrate for 2-3 hours or until gamma oscillations had stabilised. All other drugs were bath applied to slices 
at known concentrations: UBP302 ((S)-3-(2-carboxybenzyl)willardiine; gift from Dr. David Jane, Department of Pharmacology, University of Bristol, UK) at $10 \mu \mathrm{M}$; ATPA ((RS)-2-amino-3-(3-hydroxy-5-tert-butylisoxazol-4yl)propanoic acid; Tocris Cookson, Bristol, UK) at $1-5 \mu \mathrm{M}$; NS3763 (5-carboxy-2,4-di-benzamido-benzoic acid; Tocris, Bristol, UK) at 10-15 $\mu \mathrm{M}$; NBQX (2,3-dihydroxy-6-nitro7-sulfamoyl-benzo[f] quinoxaline; Tocris, Bristol, UK) at 1-10 $\mu \mathrm{M}$; and Carbachol (Sigma, UK) at 10-20 $\mu \mathrm{M}$.

\subsection{Data acquisition}

An AppleMac computer with the Axograph OSX software package (AxographX, Dr. John Clements, Australia) was used for all data acquisition. Signals were analogue filtered at 0.01$0.3 \mathrm{kHz}$ and then digitized at a frequency of $10 \mathrm{kHz}$. Power spectra were constructed, where power at a given gamma frequency was defined as the area under the peak between 20 and $80 \mathrm{~Hz}$. Power spectra were generated from digitized data, using 60 second epochs of recorded activity, and it was from these spectra that values for gamma oscillation peak frequency, peak amplitude, and spectral area power in the gamma frequency band were obtained.

\subsection{Data analysis}

Data analysis was carried out using Excel and Kaleidagraph software packages. Kaleidagraph software was used to generate pooled power spectra, and the Excel package was used to calculate the mean and standard error of mean (SEM) of results, and to draw up histograms and line graphs. All data is presented as mean \pm SEM. SigmaStat (Systat software, USA) was used for all statistical tests. Normality tests were carried out, and if data was found to be normally distributed, two-tailed paired $t$-tests were run. However, if data failed the normality test, the Wilcoxon signed rank test was carried out. This provided us with $P$-values for all data sets, and the significance level was set at $95 \%$; values less than $P=.05$ were deemed to be statistically significant.

\section{RESULTS}

\subsection{Induction of kainate-driven gamma oscillations in the MEC}

Previously, it has been demonstrated that low concentrations of kainic acid (kainate) evoke gamma frequency activity in the rat MEC in vitro $[26,27]$. In this investigation, we produced persistent gamma oscillations in the MEC by bath application of kainate (400 nM) (Figure 1). Robust gamma frequency oscillations $(39.4 \pm 1.6 \mathrm{~Hz} ; n=17)$ were evoked in layer III of the MEC in all slices to which kainate had been applied $(n=17)$. This activity was generated within 15 minutes of kainate superfusion, a stable baseline was observed after 60-90 minutes. As previously reported [19], application of the competitive AMPA/KAR antagonist NBQX $(10 \mu \mathrm{M})$ effectively abolished these kainate-induced gamma oscillations $(n=3)$ (Figure 1$)$.

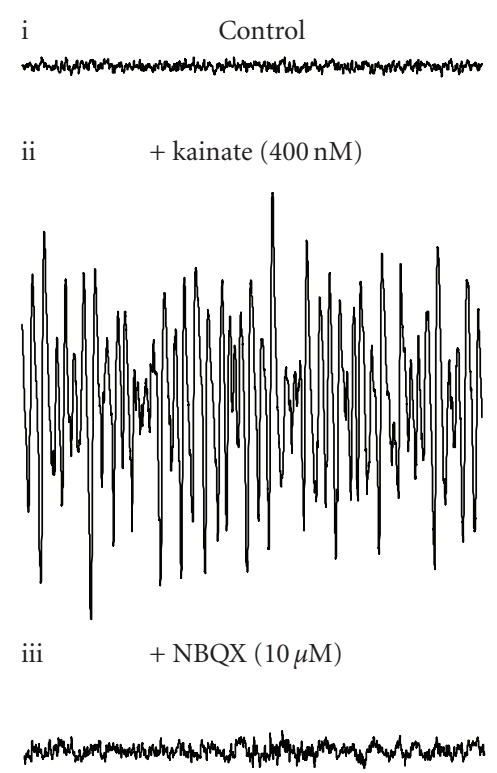

FIgURE 1: Gamma frequency oscillations can be induced in layer III of the MEC by application of kainate. (a) Extracellular field recordings showing 1 second epochs of activity (i) in control setting, (ii) following application of $400 \mathrm{nM}$ kainate, and (iii) following application of $10 \mu \mathrm{M}$ NBQX in the presence of $400 \mathrm{nM}$ kainate. Scale bar represents 200 milliseconds and $100 \mu \mathrm{V}$.

\subsection{A role for $\mathrm{GLU}_{K 5}$-containing $\mathrm{KARs}$ in the maintenance of kainate-driven gamma oscillations}

A possible role for $\mathrm{GLU}_{\mathrm{K} 5}$-containing KARs in the maintenance of kainate-driven gamma frequency oscillations in the MEC was investigated by testing the ability of the GLU $_{\mathrm{K} 5}$ selective antagonist, UBP302, to inhibit preestablished kainate-induced gamma activity. Gamma oscillations were generated in the MEC by bath application of kainate $(400 \mathrm{nM})$ and allowed to stabilise $(n=9)$ (Figure $2(\mathrm{a}))$. In the presence of UBP302 $(10 \mu \mathrm{M})$, the amplitude of kainateinduced gamma oscillations was significantly reduced (control, $116.7 \pm 44.1 \mu \mathrm{V}^{2} / \mathrm{Hz} ;$ v. UBP302, $70.0 \pm 30.3 \mu \mathrm{V}^{2} / \mathrm{Hz}$; $P<.05 ; n=9)$, and area power of oscillations was also significantly decreased (control, $1586.0 \pm 503.3 \mu \mathrm{V}^{2} / \mathrm{Hz} . \mathrm{Hz} ; v$. UBP302, $1155.1 \pm 441.4 \mu \mathrm{V}^{2} / \mathrm{Hz} . \mathrm{Hz} ; P<.05 ; n=9$ ) (Figures 2(a), 2(b)). However, following UBP302 application, the frequency of oscillations remained unchanged (control, $40.4 \pm 2.1 \mathrm{~Hz}$; v. UBP302, $38.9 \pm 2.6 \mathrm{~Hz} ; P>.1 ; n=9)$. Washout of the effects of UBP302 on gamma frequency oscillations could not be achieved $(n=9)$ (Figures 2(a), 2(b)).

\subsection{A role for $\mathrm{GLU}_{K 5}$-containing KARs in the generation of gamma oscillations in the MEC}

To investigate the role that $\mathrm{GLU}_{\mathrm{K} 5}$-containing KARs may play in the induction of kainate-driven gamma oscillations, 

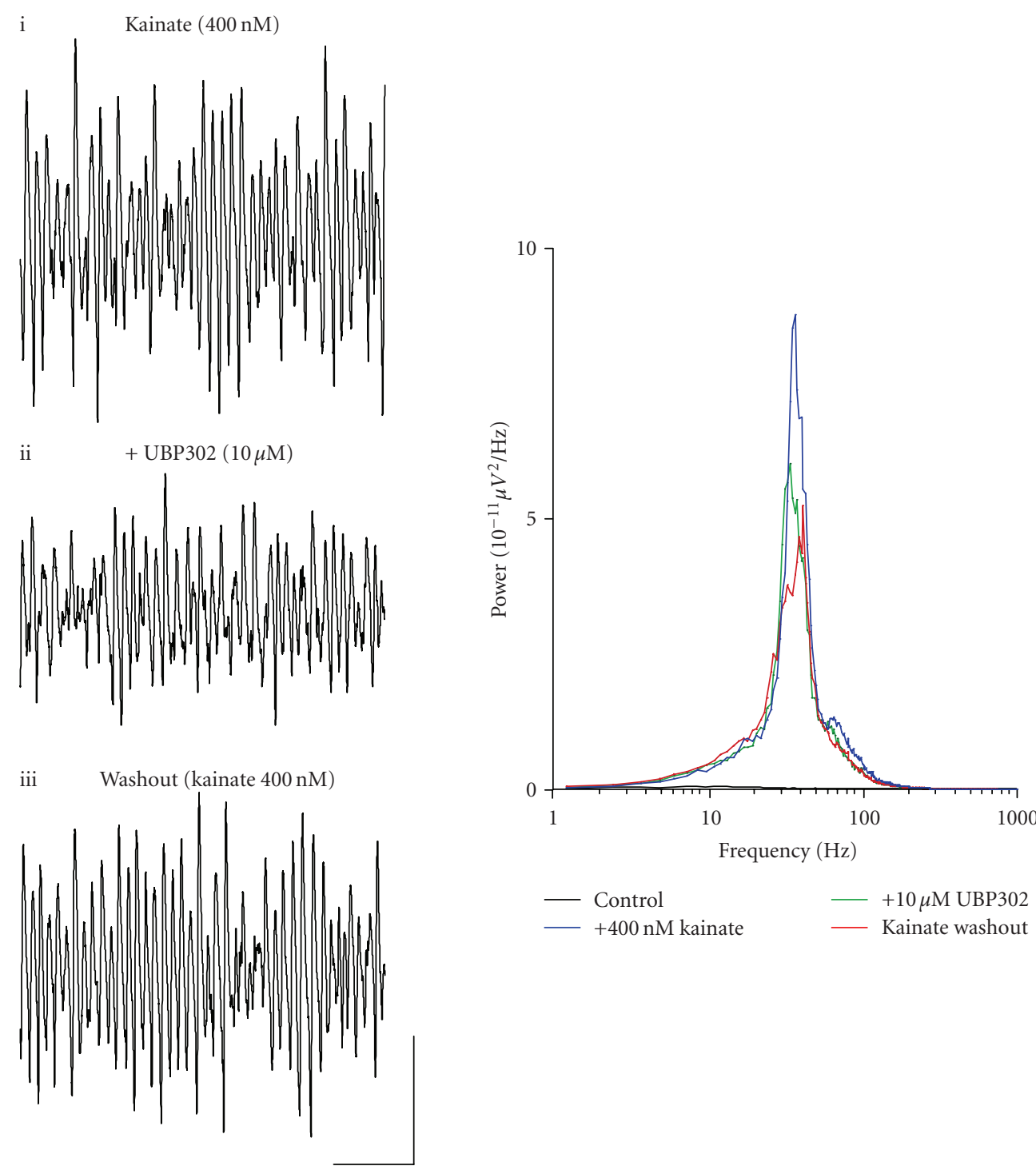

(a)

(b)

FIGURE 2: Antagonizing GLU $\mathrm{K}_{5}$-containing KARs with UBP302 inhibits kainate-driven gamma frequency oscillations in the MEC. (a) Extracellular field recordings showing 1 second epochs of activity (i) in the presence of $400 \mathrm{nM}$ kainate, (ii) following $10 \mu \mathrm{M}$ UBP302 application, and (iii) during a washout period into $400 \mathrm{nM}$ kainate. (b) Pooled power spectra $(n=9)$ produced from 60 second epochs of extracellular field recorded data, showing a control recording (black), a recording in the presence of $400 \mathrm{nM}$ kainate (blue), application of $10 \mu \mathrm{M}$ UBP302 (green), and washout back into $400 \mathrm{nM}$ kainate (red). Scale bar represents 200 milliseconds and $100 \mu \mathrm{V}$.

we carried out two experiments, using the selective $\mathrm{GLU}_{\mathrm{K} 5}-$ containing KAR agonist, ATPA, and antagonist, UBP302.

First, we tested the ability of UBP302 to inhibit the generation of a kainate-driven gamma frequency oscillation in the MEC. Slices were preincubated in UBP302 $(10 \mu \mathrm{M})$ for 30 minutes. As expected, UBP302 administration caused no neuronal network activity in slices $(n=11)$ (Figure 3(a)). However, when kainate was applied to slices following preincubation with UBP302, gamma frequency oscillations were generated in all slices $(n=11)$ (Figure 3(a)). On washout into kainate alone $(400 \mathrm{nM})$, although the frequency of oscillations did not change significantly (in presence of kainate following preincubation with UBP302, $45.4 \pm 2.0 \mathrm{~Hz}$; v. $400 \mathrm{nM}$ kainate alone, $40.3 \pm 0.9 \mathrm{~Hz} ; P>.05 ; n=11$ ), oscillations were seen to increase significantly in both peak amplitude (in presence of kainate following preincubation with UBP302, $39.2 \pm 12.1 \mu \mathrm{V}^{2} / \mathrm{Hz} ; v .400 \mathrm{nM}$ kainate alone, $122.9 \pm 32.8 \mu \mathrm{V}^{2} / \mathrm{Hz} ; P<.05 ; n=11$ ) and area power (in presence of kainate following preincubation with UBP302, $545.1 \pm 159.6 \mu \mathrm{V}^{2} / \mathrm{Hz} . \mathrm{Hz} ;$ v. $400 \mathrm{nM}$ kainate alone, $1302.5 \pm$ $241.4 \mu \mathrm{V}^{2} / \mathrm{Hz} . \mathrm{Hz} ; P<.05 ; n=11$ ) (Figures $3(\mathrm{a}), 3(\mathrm{~b})$ ).

We next investigated whether gamma frequency oscillations could be generated in the MEC by application of the GLU $_{\mathrm{K} 5}$ selective agonist, ATPA. ATPA was bath applied to slices at concentrations of $1 \mu \mathrm{M}, 2 \mu \mathrm{M}$, and $5 \mu \mathrm{M}$. ATPA induced gamma frequency oscillations in the MEC in the 
i Preincubation UBP302 $(10 \mu \mathrm{M})$

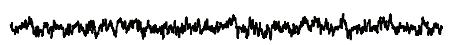

ii + kainate $(400 \mathrm{nM})$

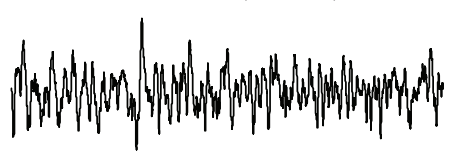

iii Washout (kainate $400 \mathrm{nM}$ )

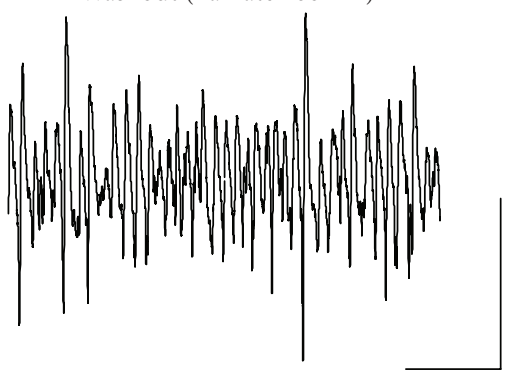

(a)

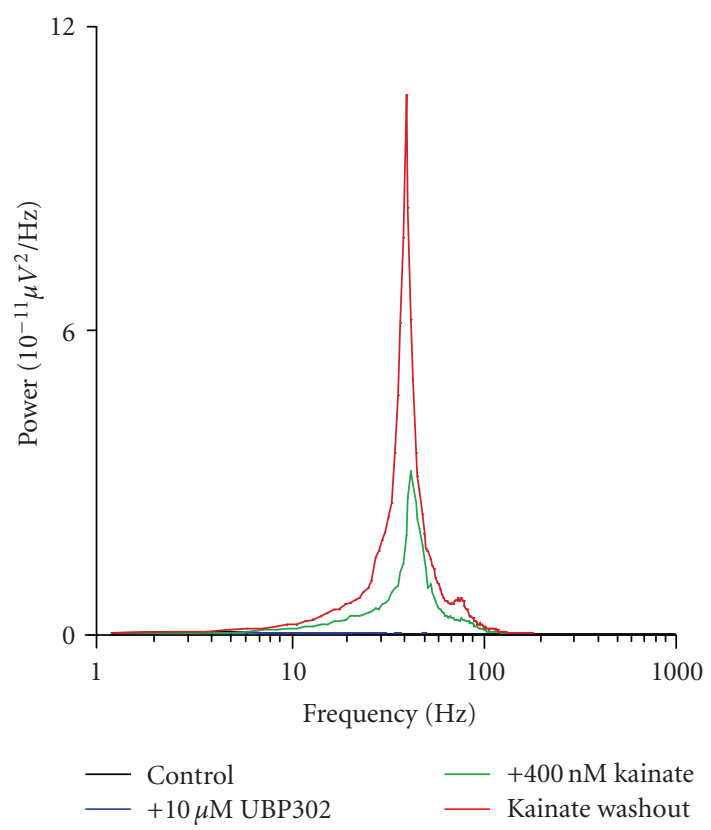

(b)

FIGURE 3: Preincubation of slices in UBP302 inhibits the ability of the MEC network to produce kainate-driven gamma frequency oscillations. (a) Extracellular field recordings showing 1 second epochs of activity (i) following preincubation with $10 \mu \mathrm{M}$ UBP302, (ii) following application of $400 \mathrm{nM}$ kainate onto preincubated slices, and (iii) during a washout period into $400 \mathrm{nM}$ kainate. (b) Pooled power spectra $(n=11)$ produced from 60 second epochs of extracellular field recorded data, showing a control recording (black), a recording following $10 \mu \mathrm{M}$ UBP302 preincubation (blue), $400 \mathrm{nM}$ kainate application following preincubation (green), and washout into $400 \mathrm{nM}$ kainate (red). Scale bar represents 200 milliseconds and $100 \mu \mathrm{V}$.

majority of slices to which the agonist was applied $(n=18$ out of a total $n=26$ ) (Figure 4(a)). Slices showing gamma oscillations upon ATPA application were observed to be dorsal MEC slices. Upon increasing the concentration of ATPA in slices demonstrating gamma oscillations, the mean frequency, peak amplitude, and area power of oscillations increased $(n=10)$ (Figures 4(a), 4(b)). The frequency of oscillations increased from $23.0 \pm 1.9 \mathrm{~Hz}$, to $34.0 \pm$ $2.4 \mathrm{~Hz}$, and to $44.2 \pm 1.5 \mathrm{~Hz}(n=10)$ (Figure $4(\mathrm{~b}))$, the peak amplitude increased from $0.9 \pm 0.5 \mu \mathrm{V}^{2} / \mathrm{Hz}$, to $4.1 \pm$ $2.3 \mu \mathrm{V}^{2} / \mathrm{Hz}$, and to $23.3 \pm 8.7 \mu \mathrm{V}^{2} / \mathrm{Hz}(n=10)$ (Figure 4(b)), and the power increased from $23.1 \pm 12.6 \mu \mathrm{V}^{2} / \mathrm{Hz}$. Hz, to $88.4 \pm 38.9 \mu \mathrm{V}^{2} / \mathrm{Hz} . \mathrm{Hz}$, and to $201.8 \pm 71.0 \mu \mathrm{V}^{2} / \mathrm{Hz} . \mathrm{Hz}$, at the respective concentrations of ATPA $(1 \mu \mathrm{M}, 2 \mu \mathrm{M}$, and $5 \mu \mathrm{M})(n=10)$ (Figure $4(\mathrm{~b}))$. Control readings, taken before ATPA administration, showed that no network activity was spontaneously present in slices $(n=26)$ (Figure $4(\mathrm{a}) \mathrm{i})$. ATPAinduced gamma frequency oscillations were susceptible to the AMPA/KAR antagonist NBQX $(10 \mu \mathrm{M})(n=3)$.

We next investigated the effect of UBP302 on ATPAinduced gamma frequency oscillations in the MEC. Gamma frequency oscillations were induced in slices by bath application of ATPA $(2-5 \mu \mathrm{M})(n=4)$ (Figure 5(a)i). UBP302 $(10 \mu \mathrm{M})$ application caused no significant change in the frequency of gamma oscillations (control, $42.7 \pm 3.9 \mathrm{~Hz}$; v. UBP302, $33.9 \pm 7.3 \mathrm{~Hz} ; P>.1 ; n=4)$ and yet had significant effects on both the peak amplitude (control, $20.8 \pm 7.1 \mu \mathrm{V}^{2} / \mathrm{Hz} ; v$. UBP302, $\left.6.6 \pm 2.8 \mu \mathrm{V}^{2} / \mathrm{Hz} ; P<.05 ; n=4\right)$ and power of oscillations (control, $359.7 \pm 117.9 \mu \mathrm{V}^{2} / \mathrm{Hz} . \mathrm{Hz}$; v. UBP302, $\left.141.7 \pm 61.9 \mu \mathrm{V}^{2} / \mathrm{Hz} . \mathrm{Hz} ; P<.05 ; n=4\right)$ (Figures 5(a)ii, 5(b)). The effects of UBP302 on an ATPAinduced gamma frequency oscillations were not reversible on washout $(n=4)$.

\subsection{A role for homomeric $\mathrm{GLU}_{K 5}$-containing KARs in gamma frequency oscillations}

The GLU $_{\mathrm{K} 5}$ selective KAR antagonist, NS3763, was used to investigate the contribution of homomeric $\mathrm{GLU}_{\mathrm{K} 5}$ containing KARs to gamma activity in the MEC. NS3763 selectively antagonises homomeric GLU $\mathrm{K}_{5}$ KARs [39] and experiments were carried out to determine the role of these homomeric receptors in both kainate- and ATPA-induced gamma oscillations.

Application of NS3763 $(10-15 \mu \mathrm{M})$ caused significant decreases in both peak amplitude (control, $100.2 \pm$ $48.4 \mu \mathrm{V}^{2} / \mathrm{Hz} ; v$. NS3763, $46.0 \pm 23.7 \mu \mathrm{V}^{2} / \mathrm{Hz} ; P<.05 ; n=$ 8 ) and area power (control, $822.9 \pm 273.2 \mu \mathrm{V}^{2} / \mathrm{Hz} . \mathrm{Hz} ; v$. NS3763, $\left.449.4 \pm 182.3 \mu \mathrm{V}^{2} / \mathrm{Hz} . \mathrm{Hz} ; P<.05 ; n=8\right)$ of kainateinduced gamma oscillations in the MEC (Figures 6(a), 6(b)). However, no effect was seen on the frequency of kainategenerated oscillations (control, $38.3 \pm 2.7 \mathrm{~Hz} ; v$. NS3763, $36.0 \pm 1.5 \mathrm{~Hz} ; P>.1 ; n=8$ ) (Figure 6(b)).

Application of NS3763 $(10-15 \mu \mathrm{M})$ to slices demonstrating ATPA-induced gamma oscillations caused no significant change in the frequency of oscillations (control, 

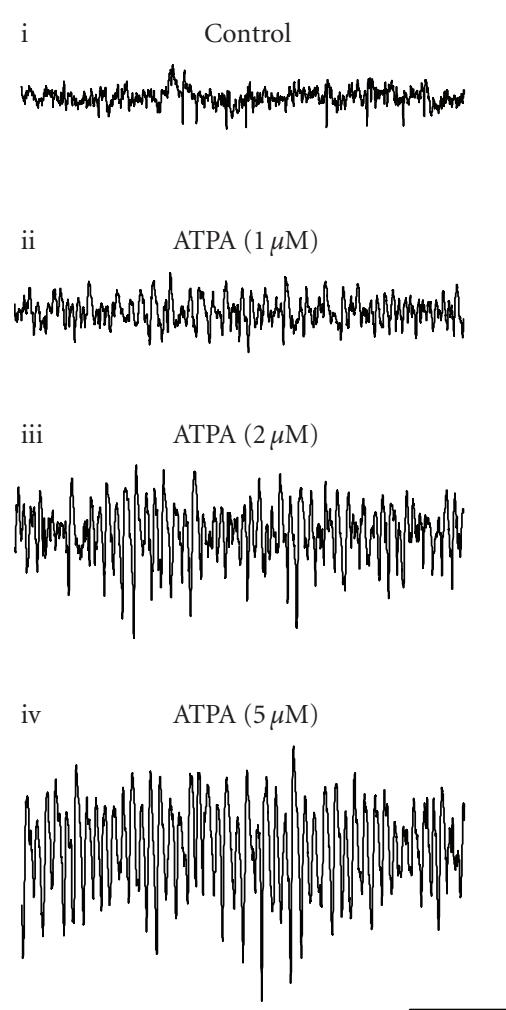

(a)
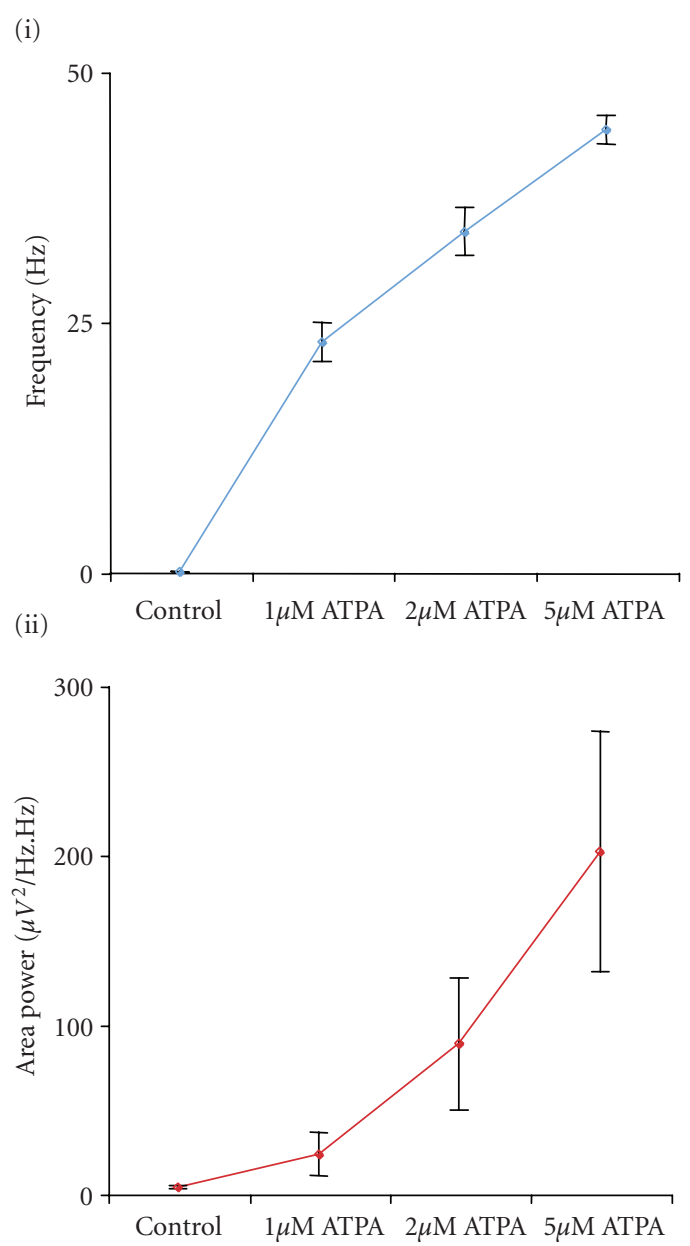

(iii)

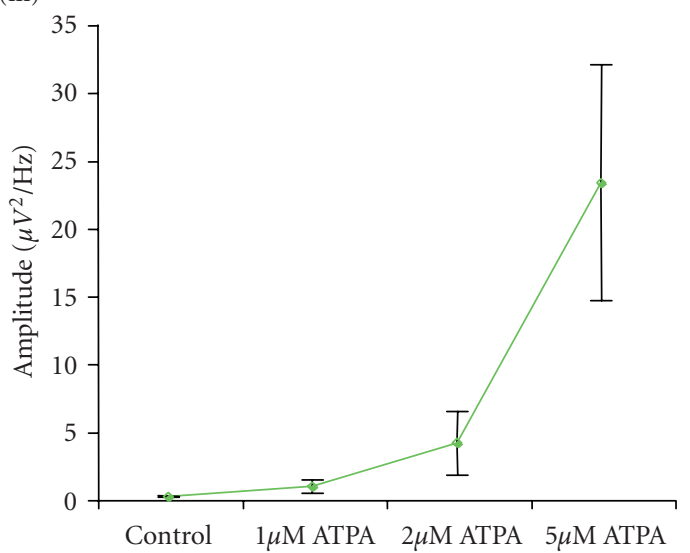

(b)

FIGURE 4: Activation of $\mathrm{GLU}_{\mathrm{K} 5}$-containing KARs can induce gamma frequency oscillations in the MEC. (a) Extracellular field recordings showing 1 second epochs of activity in a control setting (i) following application of $1 \mu \mathrm{M}$, (ii) $2 \mu \mathrm{M}$ (iii), and $5 \mu \mathrm{M}$ ATPA (iv). (b) Pooled line graphs $(n=10)$ demonstrating the effects of varying ATPA concentration on (i) frequency, (ii) area power, and (iii) peak amplitude of gamma oscillations in the MEC. Scale bar represents 200 milliseconds and $100 \mu \mathrm{V}$.

$46.7 \pm 3.8 \mathrm{~Hz} ;$ v. NS3763, $38.5 \pm 6.2 \mathrm{~Hz} ; P>.1 ; n=8)$ (Figures 7(a), 7(b)). However, the presence of NS3763 caused a significant decrease in both the peak amplitude (control, $191.9 \pm 63.1 \mu \mathrm{V}^{2} / \mathrm{Hz} ; v$. NS3763, $28.5 \pm 13.6 \mu \mathrm{V}^{2} / \mathrm{Hz} ; P<.05$; $n=8$ ) and area power (control, $1192.9 \pm 342.8 \mu \mathrm{V}^{2} / \mathrm{Hz} . \mathrm{Hz}$; v. NS3763, $\left.333.6 \pm 120.5 \mu \mathrm{V}^{2} / \mathrm{Hz} . \mathrm{Hz} ; P<.05 ; n=8\right)$ of gamma oscillations (Figures 7(a), 7(b)). The effects of NS3763 on either kainate- or ATPA-induced gamma 


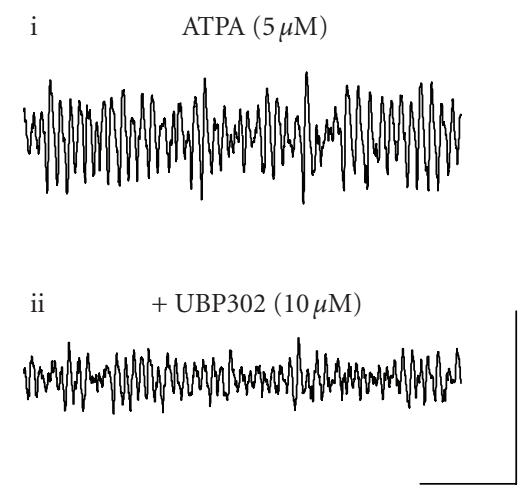

(a)

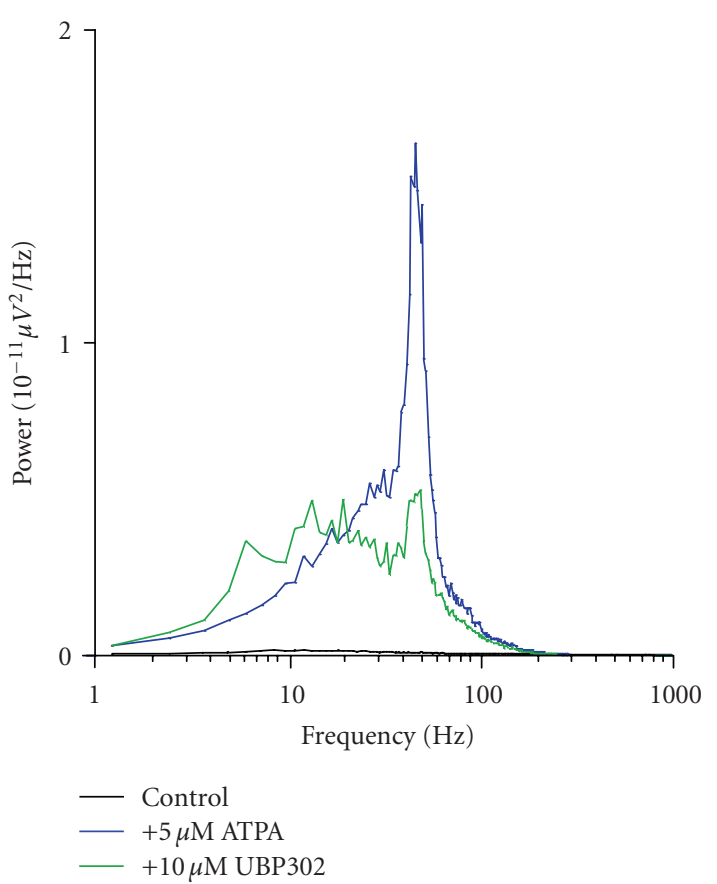

(b)

FIGURE 5: ATPA-generated gamma frequency oscillations in the MEC are reduced by application of the GLU $\mathrm{K}_{5}$ selective antagonist, UBP302. (a) Extracellular field recordings showing 1 second epochs of activity (i) in the presence of $5 \mu \mathrm{M}$ ATPA and (ii) following application of $10 \mu \mathrm{M}$ UBP302. (b) Pooled power spectra $(n=4)$ produced from 60 second epochs of extracellular field recorded data, showing a control recording (black), recording in the presence of $5 \mu \mathrm{M}$ ATPA (blue), and application of $10 \mu \mathrm{M}$ UBP302 (green). Scale bar represents 200 milliseconds and $100 \mu \mathrm{V}$.

frequency oscillations were not reversible on washout $(n=$ 12).

\subsection{A role for $\mathrm{GLU}_{K 5}$-containing KARs in carbachol-induced gamma oscillations}

Cortical gamma frequency oscillations can also be induced by application of carbachol, an agonist at muscarinic acetylcholine receptors (mAChRs) [24, 25, 45-49]. It is unclear as to the role of $\mathrm{GLU}_{\mathrm{K} 5}$-containing KARs in a cholinergicmediated gamma frequency oscillation in the MEC. Carbachol will cause an increase in the release of glutamate in the form of rhythmic EPSPs [46]. This, in turn, may lead to activation of KARs [50]. In agreement with previous studies in the MEC $[24,25]$ bath application of carbachol (10$20 \mu \mathrm{M})$ generated persistent gamma frequency oscillations ( $n$ $=6$ ) (Figure 8(a)i). Application of UBP302 $(10 \mu \mathrm{M})$ had no significant effect on the frequency (control, $41.7 \pm 1.6 \mathrm{~Hz}$; v. UBP302, $40.3 \pm 0.6 \mathrm{~Hz} ; P>.1 ; n=6$ ), peak amplitude (control, $5.9 \pm 3.1 \mu \mathrm{V}^{2} / \mathrm{Hz} ; v$. UBP302, $5.5 \pm 2.5 \mu \mathrm{V}^{2} / \mathrm{Hz} ; P$ $>.1 ; n=6$ ) or power (control, $155.2 \pm 72.7 \mu \mathrm{V}^{2} / \mathrm{Hz} . \mathrm{Hz}$; v. UBP302, $\left.148.7 \pm 62.8 \mu \mathrm{V}^{2} / \mathrm{Hz} . \mathrm{Hz} ; P>.1 ; n=6\right)$ of preestablished carbachol-driven gamma oscillations (Figures 8(a)ii, 8(b)). This lack of effect was further demonstrated by washout back into carbachol causing no significant change in observed gamma frequency oscillations (Figures 8(a)iii, $8(\mathrm{~b}))$.

\section{DISCUSSION}

A number of studies have examined the contribution of various KAR subunits to gamma frequency oscillations in the hippocampus in vitro. Fisahn et al. [10] focused on the roles of $\mathrm{GLU}_{\mathrm{K} 5}$ and $\mathrm{GLU}_{\mathrm{K} 6}$ subunits in kainateinduced hippocampal gamma oscillations, using brain slices from transgenic $\mathrm{GLU}_{\mathrm{K} 5}$ and $\mathrm{GLU}_{\mathrm{K} 6}$ receptor knockout mice. Knockout of $\mathrm{GLU}_{\mathrm{K} 5}$ caused increased sensitivity of the hippocampal network to the effects of kainate and higher susceptibility to oscillatory and epileptogenic activity. Slices from $\mathrm{GLU}_{\mathrm{K} 6}$-knockout mice could not support kainate-induced gamma oscillations or epileptiform activity, suggesting distinct roles for $\mathrm{GLU}_{\mathrm{K} 5}$ and $\mathrm{GLU}_{\mathrm{K} 6}$ subunits in the hippocampus. Fisahn et al. [10] concluded that $\mathrm{GLU}_{\mathrm{K} 5}$-containing receptors may be expressed on axons of hippocampal interneurons and have a function in inhibitory tone, and that $\mathrm{GLU}_{\mathrm{K} 6}$-containing KARs may be found in the somatodendritic region of pyramidal cells and interneurons, and provide excitatory drive. Functional receptors of both subtypes must interact to allow generation of stable gamma oscillations in the hippocampus $[9,10]$.

Subsequently, Brown et al. [51] used pharmacological approaches to investigate the role of $\mathrm{GLU}_{\mathrm{K} 5}$-containing receptors in hippocampal gamma oscillations. This study used the $\mathrm{GLU}_{\mathrm{K} 5}$-selective agonists ATPA and iodowillardiine but found that neither could induce gamma network activity in area CA3 of rat hippocampal slices. The $\mathrm{GLU}_{\mathrm{K} 5}$ selective 


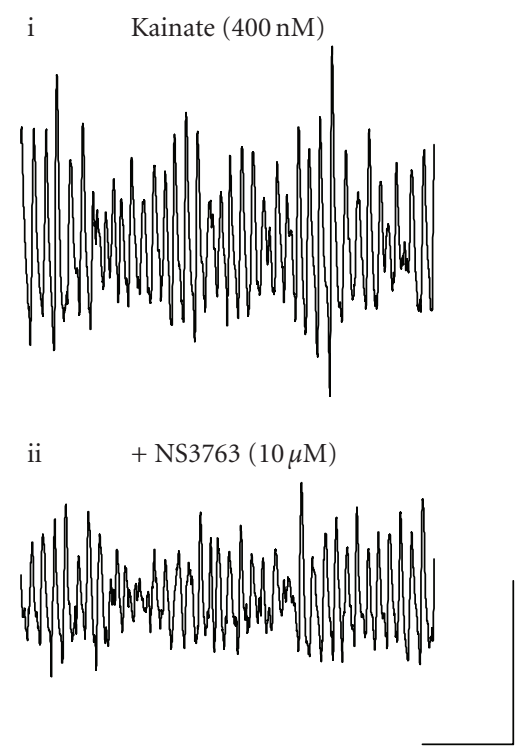

(a)

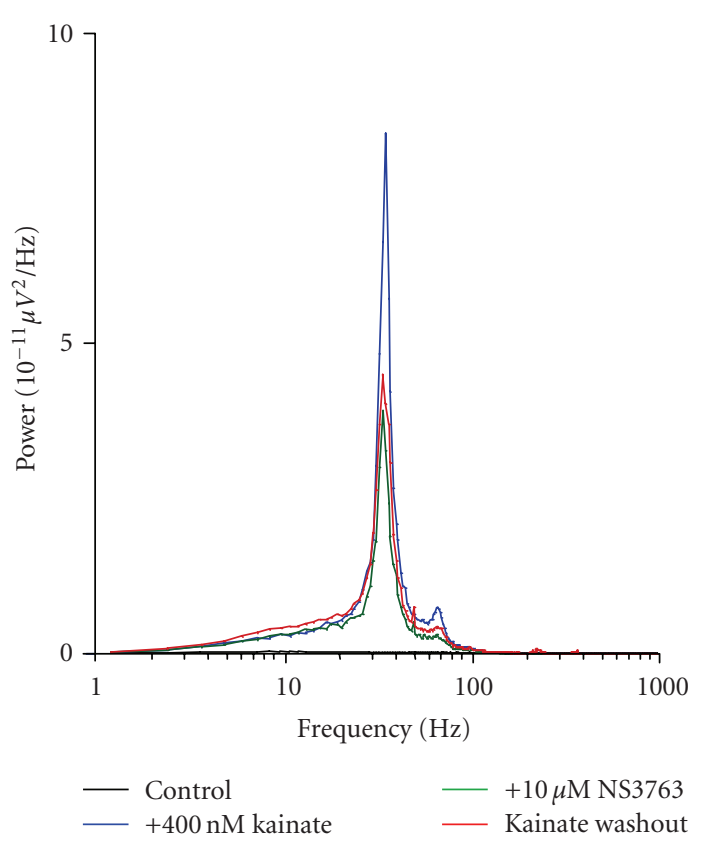

(b)

FIGURE 6: Blocking homomeric $\mathrm{GLU}_{\mathrm{K} 5}$-containing KARs significantly reduces kainate-driven gamma frequency oscillations in the MEC. (a) Extracellular field recordings showing 1 second epochs of activity (i) in the presence of $400 \mathrm{nM}$ kainate and (ii) following application of $10 \mu \mathrm{M}$ NS3763. (b) Pooled power spectra $(n=8)$ produced from 60 second epochs of extracellular field recorded data, showing a control recording (black), recording in the presence of $400 \mathrm{nM}$ kainate (blue), application of $10 \mu \mathrm{M}$ NS3763 (green), and a washout back into $400 \mathrm{nM}$ kainate (red). Scale bar represents 200 milliseconds and $100 \mu \mathrm{V}$.

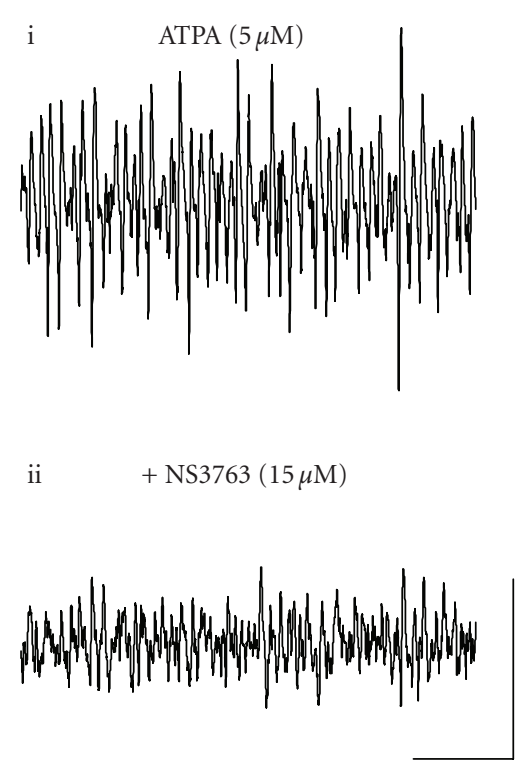

(a)

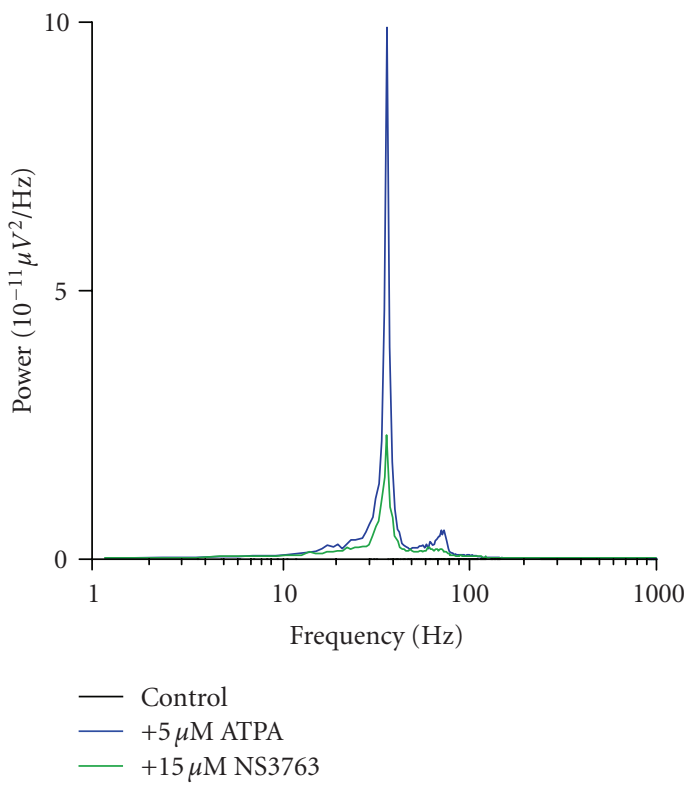

(b)

FIGURE 7: Blocking homomeric GLU $\mathrm{K}_{5}$-containing KARs effectively reduces power and amplitude of ATPA-generated gamma frequency oscillations in the MEC (a) Extracellular field recordings showing 1 second epochs of activity (i) in the presence of $5 \mu \mathrm{M}$ ATPA and (ii) following application of $15 \mu \mathrm{M}$ NS3763. (b) Pooled power spectra $(n=4)$ produced from 60 second epochs of extracellular field recorded data, showing a control recording (black), recording in the presence of $5 \mu \mathrm{M}$ ATPA (blue), and application of $15 \mu \mathrm{M}$ NS3763 (green). Scale bar represents 200 milliseconds and $100 \mu \mathrm{V}$. 


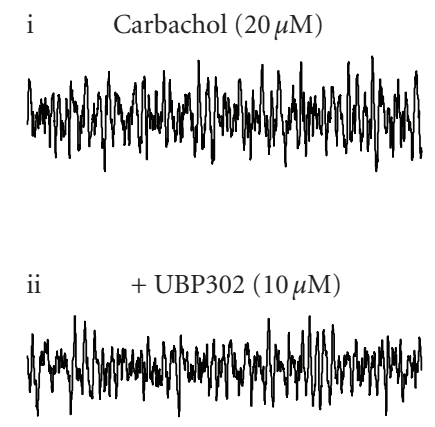

iii Washout (carbachol $20 \mu \mathrm{M}$ )

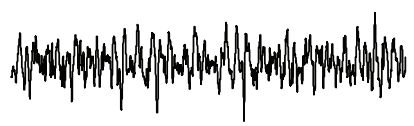

(a)

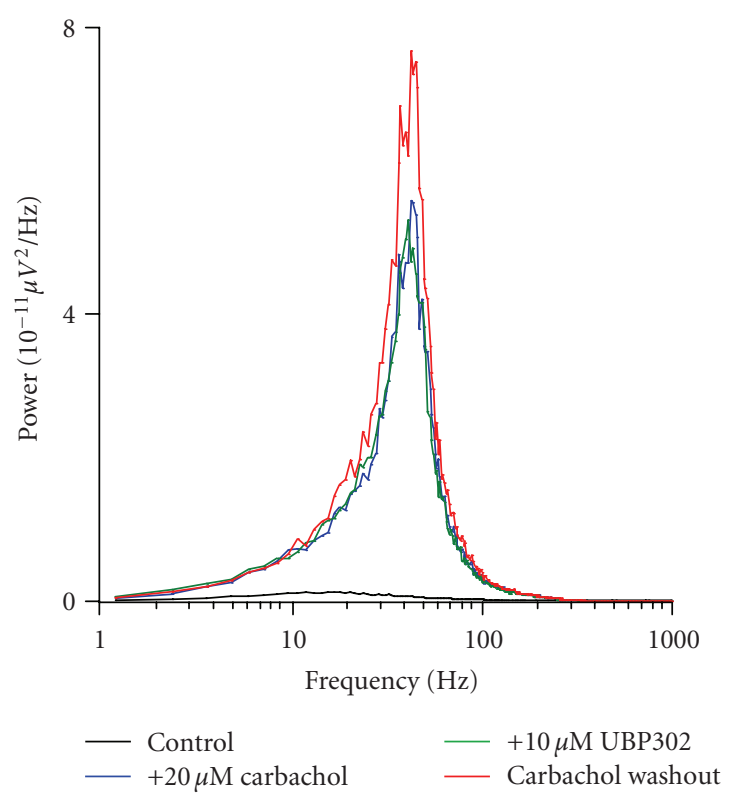

(b)

FIGURE 8: Carbachol-induced gamma frequency oscillations are not dependent on $\mathrm{GLU}_{\mathrm{K} 5}$-containing KARs. (a) Extracellular field recordings showing 1 second epochs of activity (i) in the presence of $20 \mu \mathrm{M}$ carbachol, (ii) following $10 \mu \mathrm{M}$ UBP302 application, and (iii) during a washout period into $20 \mu \mathrm{M}$ carbcahol. (b) Pooled power spectra $(n=6)$ produced from 60 second epochs of extracellular field recorded data, showing a control recording (black), recording in the presence of $20 \mu \mathrm{M}$ carbachol (blue), application of $10 \mu \mathrm{M}$ UBP302 (green), and washout back into $20 \mu \mathrm{M}$ carbachol (red). Scale bar represents 200 milliseconds and $100 \mu \mathrm{V}$.

antagonist, UBP296, when preincubated with hippocampal slices, did not prevent induction of kainate-driven gamma oscillations. However, UBP296 produced an approximately $50 \%$ reduction in the power of preestablished kainateinduced gamma frequency oscillations. This paper concluded that $\mathrm{GLU}_{\mathrm{K} 5}$-containing KARs alone cannot generate gamma oscillations in the hippocampus but may be involved in maintenance of hippocampal gamma activity generated through other KAR subtypes.

In the present study, we have demonstrated that, similarly to in the hippocampus [51], GLU $\mathrm{K}_{5}$-containing KARs in the MEC have a role in the maintenance of kainate-driven oscillations. UBP302, a $\mathrm{GLU}_{\mathrm{K} 5}$ selective antagonist, caused reductions in peak amplitude and spectral power of preestablished kainate-induced gamma frequency oscillations in the MEC. Furthermore, pretreatment of slices with UBP302 partially inhibited generation of kainate-induced gamma frequency oscillations, suggesting that $\mathrm{GLU}_{\mathrm{K} 5}$-containing KARs are at least partially responsible for the induction of gamma oscillations by kainate application. These data suggest that in the MEC, differently to in the hippocampus $[5,8,9]$, activation of $\mathrm{GLU}_{\mathrm{K} 5}$-containing KARs plays a role in the ability of MEC neuronal networks to generate gamma frequency oscillations. Moreover, in contrast to hippocampal gamma evoked by kainate, MEC gamma generated with GLU $_{\mathrm{K} 5}$ agonists demonstrates a frequency increment with increased excitatory drive. This may reflect the manifestation of fundamentally different mechanisms of local circuit gamma oscillation generation in these two regions.
It was not surprising then that application of the $\mathrm{GLU}_{\mathrm{K} 5}$ subunit selective agonist ATPA [41] successfully evoked gamma frequency oscillations in the MEC. However, care must be taken with interpretation of this data as ATPA has recently been shown not to be entirely selective for $\mathrm{GLU}_{\mathrm{K} 5}$ containing KARs [40]. In fact, ATPA can activate both homomeric and heteromeric KAR complexes containing GLU $_{\mathrm{K} 5}$, and also $\mathrm{GLU}_{\mathrm{K} 6} / \mathrm{KA} 2$ heteromeric KARs [48]. Thus, it cannot initially be assumed that these gamma oscillations have been generated via $\mathrm{GLU}_{\mathrm{K} 5}$-containing receptor complexes, since they could have been induced through $\mathrm{GLU}_{\mathrm{K} 6} / \mathrm{KA} 2$ heteromeric receptors. UBP302, however, is an antagonist with selectivity for $\mathrm{GLU}_{\mathrm{K} 5}$-containing KARs [36, 37]. Whilst UBP302 has been shown to block $\mathrm{GLU}_{\mathrm{K} 7}$ with an $\mathrm{IC}_{50}$ value of $4 \mu \mathrm{M}$-this makes it $\sim 10$-fold selective for $\mathrm{GLU}_{\mathrm{K} 5}$ versus $\mathrm{GLU}_{\mathrm{K} 7}$ - it does not have activity on $\mathrm{GLU}_{\mathrm{K} 6}$ or $\mathrm{GLU}_{\mathrm{K} 6} / \mathrm{KA} 2$ up to $100 \mu \mathrm{M}$. Indeed, some controversy surrounds the activity of UBP302 on $\mathrm{GLU}_{\mathrm{K} 7}$ as it has been reported that UBP302 failed to demonstrate any potent activity in a binding assay on $\mathrm{GLU}_{\mathrm{K} 7}$ (personal communication, D.E. Jane). In any case, as UBP302 only blocks homomeric $\mathrm{GLU}_{\mathrm{K} 7}$ and activation of $\mathrm{GLU}_{\mathrm{K} 7}$ requires very high glutamate concentrations $\left(\mathrm{EC}_{50}\right.$ value $\left.5.9 \mathrm{mM}\right)$ [52] it may not be relevant to this study. Application of UBP302 onto slices showing ATPA-generated network activity causes reduced peak amplitude and an approximately 60\% reduction in area power of gamma frequency oscillations. This inhibition of ATPA-generated gamma oscillations by UBP302 suggests that the observed activity must, at least in part, be due to activation of $\mathrm{GLU}_{\mathrm{K} 5}$-containing KARs. 
Moreover, NS3763 application caused a significant reduction in peak amplitude and spectral power of preestablished kainate-driven gamma oscillations. This demonstrates that homomeric $\mathrm{GLU}_{\mathrm{K} 5}$-containing KARs are at least partially responsible for the maintenance of these kainatedriven gamma frequency oscillations. Application of NS3763 to preestablished ATPA-generated oscillations caused an approximately $80 \%$ reduction in area power of gamma frequency oscillations and also a reduction in peak amplitude. This suggests that a large component of an ATPA-driven gamma oscillation is maintained through homomeric $\mathrm{GLU}_{\mathrm{K} 5}$ KARs. The activity of the selective homomeric $\mathrm{GLU}_{\mathrm{K} 5^{-}}$ containing KAR antagonist, NS3763, on both kainate- and ATPA-generated gamma frequency oscillations, tells us that homomeric $\mathrm{GLU}_{\mathrm{K} 5}$-containing KARs are involved in the observed network activity.

It has been suggested that carbachol-driven activity could cause excess glutamate release and that this overspill of glutamate could activate KARs [50]. The lack of effect of the $\mathrm{GLU}_{\mathrm{K} 5}$ selective antagonist, UBP302, on carbacholinduced gamma oscillations in the MEC suggests that GLU $_{\mathrm{K} 5}$-containing KARs are not involved in the generation or maintenance of gamma oscillations induced via activation of muscarinic cholinergic receptor. However, we cannot rule out the possibility that other KAR subtypes may be involved in these mAChR-mediated gamma oscillations.

We have shown that $\mathrm{GLU}_{\mathrm{K} 5}$-containing KARs are implicated in the generation and maintenance of gamma frequency oscillations in the MEC evoked by kainate. However, we can only speculate on the cellular localisation of these $\mathrm{GLU}_{\mathrm{K} 5}$-containing receptors in the MEC. Research performed by Christensen et al. [40] in the hippocampus, suggested likely localisations of KAR subtypes in hippocampal CA1 inhibitory interneurons terminating with pyramidal cells, concluding that heteromeric $\mathrm{GLU}_{\mathrm{K} 6} / \mathrm{KA} 2$ receptors are expressed in somatodendritic compartments of interneurons, and that $\mathrm{GLU}_{\mathrm{K} 5}$ complexes, with either $\mathrm{GLU}_{\mathrm{K} 6}$ or KA2, are found at presynaptic terminals. It seems likely from our results that in the MEC, both homomeric and heteromeric $\mathrm{GLU}_{\mathrm{K} 5}$-containing KARs are present.

Presynaptic KARs are involved in regulation and modulation of neurotransmitter release at inhibitory and excitatory synapses in the hippocampus [50, 53, 54]. In contrast, postsynaptic KARs mediate excitatory postsynaptic currents (EPSCs) in many brain regions $[35,55]$. KAR activation in the hippocampus modulates GABA release at terminals of inhibitory interneurons and causes an increase in spontaneous IPSCs but a reduction in the amplitude of these IPSCs impinging on to CA1 interneurons [40]. This suggests that KARs may be present in two distinct populations in hippocampal inhibitory interneurons, and the same may be true of KARs in the MEC $[2,40]$. However, other reports have demonstrated that kainate can increase the frequency and amplitude of spontaneous IPSCs, but not action potential-independent miniature IPSCs in stratum radiatum interneurons [56]. Moreover, these authors also observed that kainate can directly depolarise the axonal plexus of inhibitory interneurons producing both increased antidromic and presumably orthodromic spiking. This effect would explain the ability of KAR activation to increase spontaneous but not miniature IPSC activity. The presence of KARs at an axonal loci has been well documented in the hippocampus, most notably in mossy fibres $[57,58]$.

As outlined in the previous paragraph, there is a large corpus of data on the role of KAR in the hippocampus. However, with respect to the MEC there is a paucity of such information. In order to put the current results presented in this paper into context, future work will concentrate on combining intracellular recordings from individual neurones (pyramidal and interneuron), specific pharmacological KAR tools, and transgenic KAR subunit knockout animals $[9,10]$ to elucidate the exact nature of cellular expression of KARs in the MEC.

\section{REFERENCES}

[1] M. Hollmann and S. Heinemann, "Cloned glutamate receptors," Annual Review of Neuroscience, vol. 17, pp. 31-108, 1994.

[2] J. Lerma, A. V. Paternain, A. Rodríguez-Moreno, and J. C. López-García, "Molecular physiology of kainate receptors," Physiological Reviews, vol. 81, no. 3, pp. 971-998, 2001.

[3] W. Wisden and P. H. Seeburg, "A complex mosaic of high-affinity kainate receptors in rat brain," The Journal of Neuroscience, vol. 13, no. 8, pp. 3582-3598, 1993.

[4] B. Bettler and C. Mulle, "Neurotransmitter receptors II. AMPA and kainate receptors," Neuropharmacology, vol. 34, no. 2, pp. 123-139, 1995.

[5] P. Werner, M. Voigt, K. Keinanen, W. Wisden, and P. H. Seeburg, "Cloning of a putative high-affinity kainate receptor expressed predominantly in hippocampal CA3 cells," Nature, vol. 351, no. 6329, pp. 742-744, 1991.

[6] A. Herb, N. Burnashev, P. Werner, B. Sakmann, W. Wisden, and P. H. Seeburg, "The KA-2 subunit of excitatory amino acid receptors shows widespread expression in brain and forms ion channels with distantly related subunits," Neuron, vol. 8, no. 4, pp. 775-785, 1992.

[7] R. Chittajallu, S. P. Braithwaite, V. R. J. Clarke, and J. M. Henley, "Kainate receptors: subunits, synaptic localization and function," Trends in Pharmacological Sciences, vol. 20, no. 1, pp. 26-35, 1999.

[8] C. Cui and M. L. Mayer, "Heteromeric kainate receptors formed by the coassembly of GluR5, GluR6, and GluR7," The Journal of Neuroscience, vol. 19, no. 19, pp. 8281-8291, 1999.

[9] A. Fisahn, "Kainate receptors and rhythmic activity in neuronal networks: hippocampal gamma oscillations as a tool," The Journal of Physiology, vol. 562, no. 1, pp. 65-72, 2005.

[10] A. Fisahn, A. Contractor, R. D. Traub, E. H. Buhl, S. F. Heinemann, and C. J. McBain, "Distinct roles for the kainate receptor subunits GluR5 and GluR6 in kainate-induced hippocampal gamma oscillations," The Journal of Neuroscience, vol. 24, no. 43, pp. 9658-9668, 2004.

[11] A. Bragin, G. Jandó, Z. Nádasdy, J. Hetke, K. Wise, and G. Buzsáki, "Gamma $(40-100 \mathrm{~Hz})$ oscillation in the hippocampus of the behaving rat," The Journal of Neuroscience, vol. 15, no. 1, pp. 47-60, 1995.

[12] J. J. Chrobak and G. Buzsáki, "Gamma oscillations in the entorhinal cortex of the freely behaving rat," The Journal of Neuroscience, vol. 18, no. 1, pp. 388-398, 1998.

[13] J. Csicsvari, B. Jamieson, K. D. Wise, and G. Buzsáki, "Mechanisms of gamma oscillations in the hippocampus of the behaving rat," Neuron, vol. 37, no. 2, pp. 311-322, 2003. 
[14] A. K. Engel and W. Singer, "Temporal binding and the neural correlates of sensory awareness," Trends in Cognitive Sciences, vol. 5, no. 1, pp. 16-25, 2001.

[15] W. Singer, "Synchronization of cortical activity and its putative role in information processing and learning," Annual Review of Physiology, vol. 55, pp. 349-374, 1993.

[16] C. M. Gray, P. König, A. K. Engel, and W. Singer, "Oscillatory responses in cat visual cortex exhibit inter-columnar synchronization which reflects global stimulus properties," Nature, vol. 388, no. 6213, pp. 334-337, 1989.

[17] J. Fell, P. Klaver, K. Lehnertz, et al., "Human memory formation is accompanied by rhinal-hippocampal coupling and decoupling," Nature Neuroscience, vol. 4, no. 12, pp. 12591264, 2001.

[18] J. Fell, P. Klaver, C. E. Elger, and G. Fernández, "The interaction of rhinal cortex and hippocampus in human declarative memory formation," Reviews in the Neurosciences, vol. 13, no. 4, pp. 299-312, 2002.

[19] D. Muller, I. Nikonenko, P. Jourdain, and S. Alberi, "LTP, memory and structural plasticity," Current Molecular Medicine, vol. 2, no. 7, pp. 605-611, 2002.

[20] W. Singer and C. M. Gray, "Visual feature integration and the temporal correlation hypothesis," Annual Review of Neuroscience, vol. 18, pp. 555-586, 1995.

[21] R. D. Traub, N. Spruston, I. Soltesz, A. Konnerth, M. A. Whittington, and J. G. R. Jefferys, "Gamma-frequency oscillations: a neuronal population phenomenon, regulated by synaptic and intrinsic cellular processes, and inducing synaptic plasticity," Progress in Neurobiology, vol. 55, no. 6, pp. 563-575, 1998.

[22] N. Hirai, S. Uchida, T. Maehara, Y. Okubo, and H. Shimizu, "Enhanced gamma $(30-150 \mathrm{~Hz})$ frequency in the human medial temporal lobe," Neuroscience, vol. 90, no. 4, pp. 11491155, 1999.

[23] S. Uchida, T. Maehara, N. Hirai, Y. Okubo, and H. Shimizu, "Cortical oscillations in human medial temporal lobe during wakefulness and all-night sleep," Brain Research, vol. 891, no. 1-2, pp. 7-19, 2001.

[24] S. Van der Linden, F. Panzica, and M. de Curtis, "Carbachol induces fast oscillations in the medial but not in the lateral entorhinal cortex of the isolated guinea pig brain," Journal of Neurophysiology, vol. 82, no. 5, pp. 2441-2450, 1999.

[25] C. T. Dickson, G. Biella, and M. de Curtis, "Evidence for spatial modules mediated by temporal synchronization of carbacholinduced gamma rhythm in medial entorhinal cortex," The Journal of Neuroscience, vol. 20, no. 20, pp. 7846-7854, 2000.

[26] M. O. Cunningham, C. H. Davies, E. H. Buhl, N. Kopell, and M. A. Whittington, "Gamma oscillations induced by kainate receptor activation in the entorhinal cortex in vitro," The Journal of Neuroscience, vol. 23, no. 30, pp. 9761-9769, 2003.

[27] M. O. Cunningham, D. M. Halliday, C. H. Davies, R. D. Traub, E. H. Buhl, and M. A. Whittington, "Coexistence of gamma and high-frequency oscillations in rat medial entorhinal cortex in vitro," The Journal of Physiology, vol. 559, no. 2, pp. 347-353, 2004.

[28] M. O. Cunningham, J. Hunt, S. Middleton, et al., "Regionspecific reduction in entorhinal gamma oscillations and parvalbumin-immunoreactive neurons in animal models of psychiatric illness," The Journal of Neuroscience, vol. 26, no. 10, pp. 2767-2776, 2006.

[29] M. A. Whittington, R. D. Traub, and J. G. R. Jefferys, "Synchronized oscillation in interneuron networks driven by metabotropic glutamate receptor activation," Nature, vol. 373, no. 6515 , pp. 612-615, 1995.
[30] N. Hájos, J. Pálhalini, E. O. Mann, B. Nèmeth, O. Paulsen, and T. F. Freund, "Spike timing of distinct types of GABAergic interneuron during hippocampal gamma oscillations in vitro," The Journal of Neuroscience, vol. 24, no. 41, pp. 9127-9137, 2004.

[31] T. Gloveli, T. Dugladze, S. Saha, et al., "Differential involvement of oriens/pyramidale interneurones in hippocampal network oscillations in vitro," The Journal of Physiology, vol. 562, no. 1, pp. 131-147, 2005.

[32] M. A. Whittington and R. D. Traub, "Interneuron Diversity series: inhibitory interneurons and network oscillations in vitro," Trends in Neurosciences, vol. 26, no. 12, pp. 676-682, 2003.

[33] M. O. Cunningham, M. A. Whittington, A. Bibbig, et al., "A role for fast rhythmic bursting neurons in cortical gamma oscillations in vitro," Proceedings of the National Academy of Sciences of the United States of America, vol. 101, no. 18, pp. 7152-7157, 2004.

[34] I. Bureau, S. Bischoff, S. F. Heinemann, and C. Mulle, "Kainate receptor-mediated responses in the CA1 field of wild-type and GluR6-deficient mice," The Journal of Neuroscience, vol. 19, no. 2, pp. 653-663, 1999.

[35] R. Cossart, M. Esclapez, J. C. Hirsch, C. Bernard, and Y. Ben-Ari, "GluR5 kainate receptor activation in interneurons increases tonic inhibition of pyramidal cells," Nature Neuroscience, vol. 1, no. 6, pp. 470-478, 1998.

[36] J. C. A. More, R. Nistico, N. P. Dolman, et al., "Characterisation of UBP296: a novel, potent and selective kainate receptor antagonist," Neuropharmacology, vol. 47, no. 1, pp. 46-64, 2004.

[37] N. P. Dolman, H. M. Troop, J. C. A. More, et al., "Synthesis and pharmacology of willardiine derivatives acting as antagonists of kainate receptors," Journal of Medicinal Chemistry, vol. 48, no. 24, pp. 7867-7881, 2005.

[38] D. Perrais, P. S. Pineiro, D. E. Jane, and C. Mulle, "Antagonism of recombinant and native GluR7-containing receptors: new tools to study presynaptic kainate receptors," submitted to Neuropharmacology.

[39] J. K. Christensen, T. Varming, P. K. Ahring, T. D. Jorgensen, and E. O. Nielsen, "In vitro characterisation of 5-carbozyl2,4-di-benzamido-benzoic acid (NS3763), a non-competitive antagonist of $\mathrm{GLU}_{\mathrm{K} 5}$ receptors," The Journal of Pharmacology and Experimental Theraputics, vol. 309, pp. 1003-1010, 2004.

[40] J. K. Christensen, A. V. Paternain, S. Selak, P. K. Ahring, and J. Lerma, "A mosaic of functional kainate receptors in hippocampal interneurons," The Journal of Neuroscience, vol. 24, no. 41, pp. 8986-8993, 2004.

[41] V. R. J. Clarke, B. A. Ballyk, K. H. Hoo, et al., "A hippocampal GluR5 kainate receptor regulating inhibitory synaptic transmission," Nature, vol. 389, no. 6651, pp. 599-603, 1997.

[42] V. R. J. Clarke and G. L. Collingridge, "Characterisation of the effects of ATPA, a $\mathrm{GLU}_{\mathrm{K} 5}$ receptor selective agonist, on excitatory synaptic transmission in area CA1 of rat hippocampal slices," Neuropharmacology, vol. 42, no. 7, pp. 889-902, 2002.

[43] V. R. J. Clarke and G. L. Collingridge, "Characterisation of the effects of ATPA, a GLU $\mathrm{K}_{5}$ kainate receptor agonist, on GABAergic synaptic transmission in the CA1 region of rat hippocampal slices," Neuropharmacology, vol. 47, no. 3, pp. 363-372, 2004.

[44] S. L. Campbell, S. S. Mathew, and J. J. Hablitz, "Pre- and postsynaptic effects of kainate on layer II/III pyramidal cells in rat neocortex," Neuropharmacology, vol. 53, no. 1, pp. 37-47, 2007. 
[45] A. Fisahn, F. G. Pike, E. H. Buhl, and O. Paulsen, "Cholinergic induction of network oscillations at $40 \mathrm{~Hz}$ in the hippocampus in vitro," Nature, vol. 394, no. 6689, pp. 186-189, 1998.

[46] R. D. Traub, A. Bibbig, A. Fisahn, F. E. N. Lebeau, M. A. Whittington, and E. H. Buhl, "A model of gammafrequency network oscillations induced in the rat CA3 region by carbachol in vitro," European Journal of Neuroscience, vol. 12, no. 11, pp. 4093-4106, 2000.

[47] S. G. Hormuzdi, I. Pais, F. E. N. LeBeau, et al., "Impaired electrical signaling disrupts gamma frequency oscillations in connexin 36-deficient mice," Neuron, vol. 31, no. 3, pp. 487495, 2001.

[48] J. Pálhalmi, O. Paulsen, T. F. Freund, and N. Hájos, “Distinct properties of carbachol- and DHPG-induced network oscillations in hippocampal slices," Neuropharmacology, vol. 47, no. 3, pp. 381-389, 2004.

[49] E. O. Mann, J. M. Suckling, N. Hajos, S. A. Greenfield, and O. Paulsen, "Perisomatic feedback inhibition underlies cholinergically induced fast network oscillations in the rat hippocampus in vitro," Neuron, vol. 45, no. 1, pp. 105-117, 2005.

[50] S. E. Lauri, M. Segerstråle, A. Vesikansa, et al., "Endogenous activation of kainate receptors regulates glutamate release and network activity in the developing hippocampus," The Journal of Neuroscience, vol. 25, no. 18, pp. 4473-4484, 2005.

[51] J. T. Brown, A. Teriakidis, and A. D. Randall, "A pharmacological investigation of the role of $\mathrm{GLU}_{\mathrm{K} 5}$-containing receptors in kainate-driven hippocampal gamma band oscillations," Neuropharmacology, vol. 50, no. 1, pp. 47-56, 2006.

[52] H. H. Schiffer, G. T. Swanson, and S. F. Heinemann, "Rat GluR7 and a carboxy-terminal splice variant, GluR7b, are functional kainate receptor subunits with a low sensitivity to glutamate," Neuron, vol. 19, no. 5, pp. 1141-1146, 1997.

[53] A. Contractor, G. Swanson, and S. F. Heinemann, "Kainate receptors are involved in short- and long-term plasticity at mossy fiber synapses in the hippocampus," Neuron, vol. 29, no. 1, pp. 209-216, 2001.

[54] A. Contractor, A. W. Sailer, M. Darstein, et al., "Loss of kainate receptor-mediated heterosynaptic facilitation of mossy-fiber synapses in $\mathrm{KA} 2^{-/-}$mice," The Journal of Neuroscience, vol. 23, no. 2, pp. 422-429, 2003.

[55] M. Vignes and G. L. Collingridge, "The synaptic activation of kainate receptors," Nature, vol. 388, no. 6638, pp. 179-182, 1997.

[56] A. Semyanov and D. M. Kullmann, "Kainate receptordependent axonal depolarization and action potential initiation in interneurons," Nature Neuroscience, vol. 4, no. 7, pp. 718-723, 2001.

[57] H. Kamiya and S. Ozawa, "Kainate receptor-mediated presynaptic inhibition at the mouse hippocampal mossy fibre synapse," The Journal of Physiology, vol. 523, no. 3, pp. 653 665, 2000.

[58] D. Schmitz, M. Frerking, and R. A. Nicoll, "Synaptic activation of presynaptic kainate receptors on hippocampal mossy fiber synapses," Neuron, vol. 27, no. 2, pp. 327-338, 2000. 

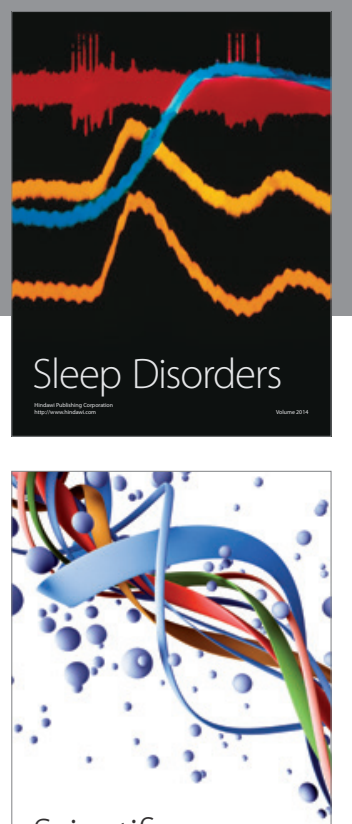

Scientifica
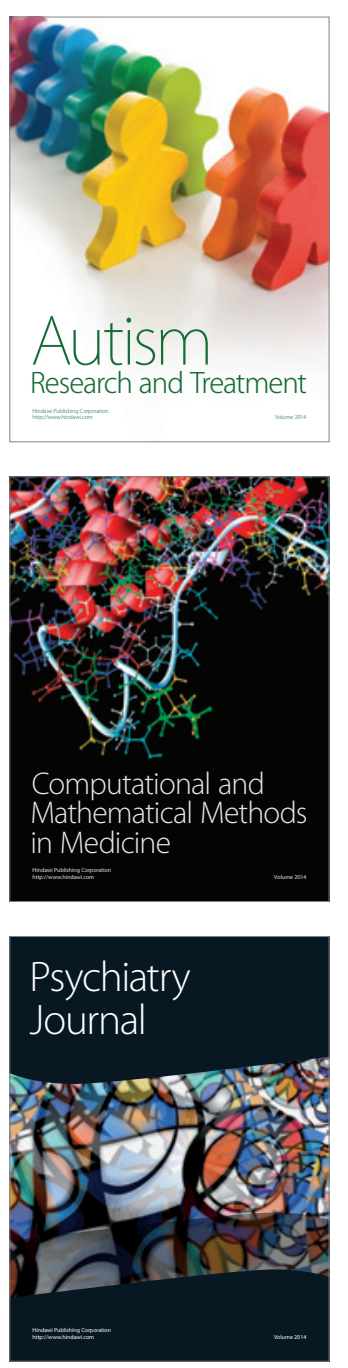
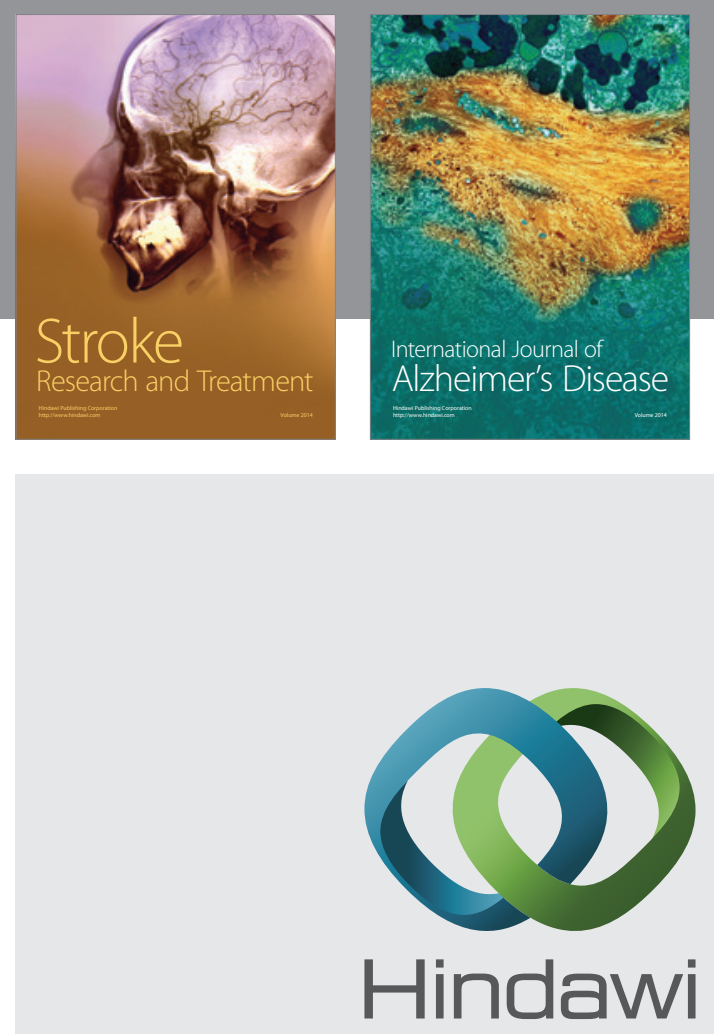

Submit your manuscripts at

http://www.hindawi.com
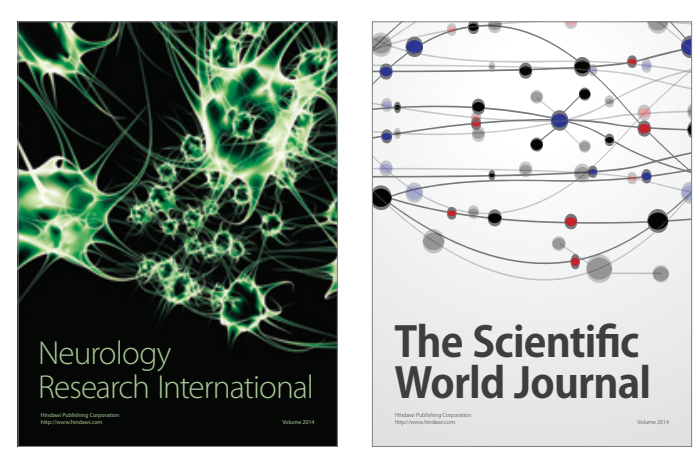

The Scientific World Journal

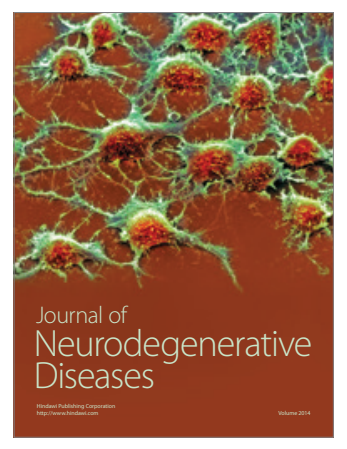

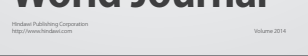

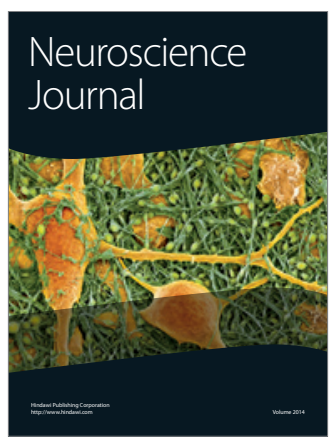

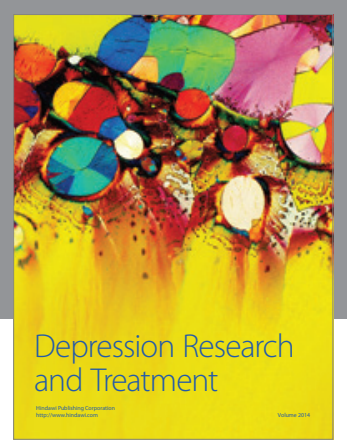
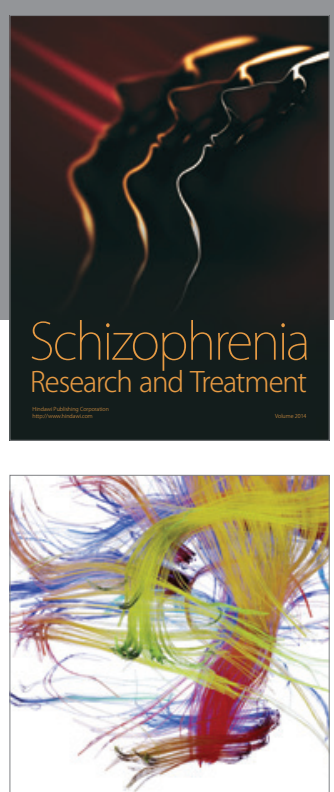

Brain Science

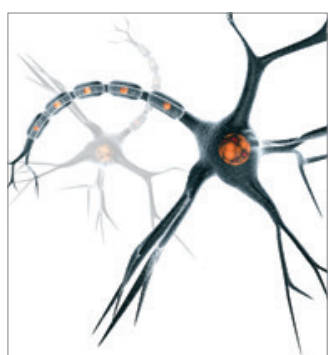

Neural Plasticity
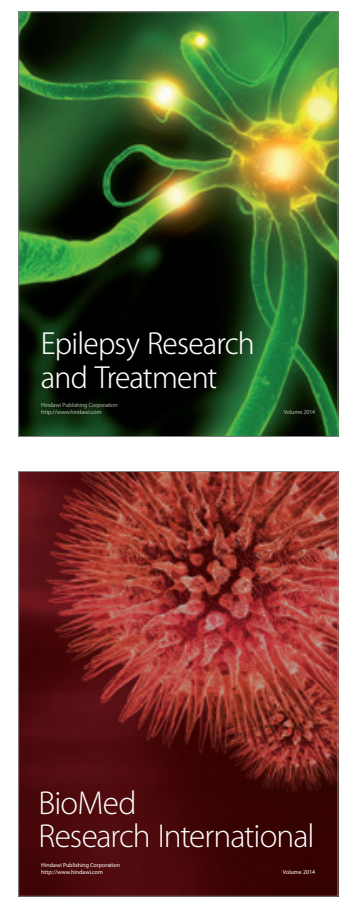

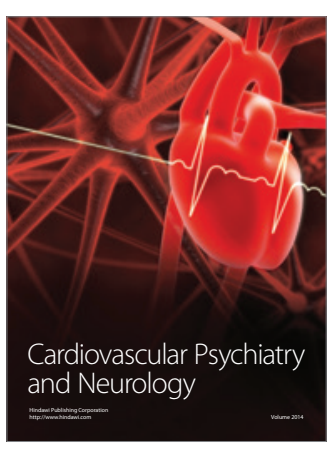

Parkinson's

Disease
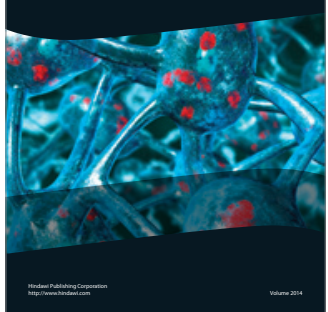